\title{
Modelling of Dissolved Oxygen Concentration During Storage of Packaged Liquid Doods
}

\author{
L. M. Ahrné ${ }^{a}$, F. A. R. Oliveira ${ }^{b *}$, M. C. Manso ${ }^{c}$, M. C. Drumond ${ }^{c}$, \\ R. Öste ${ }^{d} \&$ V.Gekas ${ }^{c}$ \\ ${ }^{a}$ Tetra Pak Processing Systems AB, S-221 86 Lund, Sweden \\ ${ }^{b}$ Instituto Inter-Universitario de Macau, R. Central no. 111, Macau \\ 'Escola Superior de Biotecnologia, Universidade Católica Portuguesa, R. Dr. António \\ Bernardino de Almeida, 4200 Porto, Portugal \\ ${ }^{d}$ Department of Applied Nutrition and Food Chemistry, Centre for Chemistry and Chemical \\ Engineering, PO Box 124, S-221 00 Lund, Sweden
}

\begin{abstract}
A mathematical model that combines oxygen uptake from the outside environment with oxygen consumption by oxidative reactions, in a liquid packed food during storage, was developed. The model was applied to orange juice aseptically packaged in Tetra Brik Aseptic cartons, during storage of up to 5 months at $4,8,20,30,40$ and $50^{\circ} \mathrm{C}$. The parameters of the model, the oxygen mass transfer coefficient and the rate constant of consumption reactions, were estimated by fitting the model to the experimental data. The value of the rate constant estimated for the system tested in this work, was three orders of magnitude greater than the value of the oxygen mass transfer coefficient. The influence of temperature on the reaction rate was well described by an Arrhenius type equation, with an activation energy of $46 \mathrm{~kJ} / \mathrm{mole}$. This model was further tested with data reported in literature and it was found that it adequately describes the dissolved oxygen concentration changes during storage.
\end{abstract}

\section{NOMENCLATURE}

$A$

$C_{\mathrm{O}_{2}}$

$C_{\mathrm{O}_{2}}^{\text {out }}$
Package surface area $\left(\mathrm{m}^{2}\right)$

Concentration of dissolved oxygen in the juice at time $t(\mathrm{ppm})$

Concentration of oxygen in the storage atmosphere (ppm)

*Author to whom correspondence should be addressed. 


\begin{tabular}{|c|c|}
\hline$C_{\mathrm{O}_{2}}^{\text {initial }}$ & Initial concentration of dissolved oxygen in the juice ( $\mathrm{ppm})$ \\
\hline$C_{\mathrm{O}_{2}}^{\mathrm{eq}}$ & Concentration of dissolved oxygen in the juice for $t \rightarrow \infty(\mathrm{ppm})$ \\
\hline$D$ & Diffusion coefficient of oxygen in the packaging material $\left(\mathrm{m}^{2} /\right.$ day $)$ \\
\hline$d$ & Thickness of the packaging material $(\mathrm{m})$ \\
\hline$E_{\mathrm{a}}$ & Activation energy $(\mathrm{kJ} / \mathrm{mole})$ \\
\hline$K$ & Rate constant $\left(\right.$ day $\left.^{-1}\right)$ \\
\hline$K_{\mathrm{R}}$ & Reaction rate constant $\left(\mathrm{day}^{-1}\right)$ \\
\hline$K_{0}$ & Pre-exponential factor of the Arrhenius equation $\left(\right.$ day $\left.^{-1}\right)$ \\
\hline$K_{\mathrm{D}}$ & $\begin{array}{l}\text { Oxygen mass transfer coefficient }\left(\text { day }^{-1}\right) \text { defined in eqn (3) and eqn } \\
(5)\end{array}$ \\
\hline$K_{\text {out }}$ & Mass transfer coefficient outside the package $(\mathrm{m} /$ day $)$ \\
\hline$K_{\text {int }}$ & Mass transfer coefficient inside the package ( $\mathrm{m} /$ day) \\
\hline$K_{\text {overall }}$ & Overall mass transfer coefficient ( $\mathrm{m} /$ day) \\
\hline & $\begin{array}{l}\text { Oxygen partition coefficient of the package material at the outside } \\
\text { wall }\end{array}$ \\
\hline$k_{\mathrm{p}}^{2}$ & $\begin{array}{l}\text { Oxygen partition coefficient of the package material at the inside } \\
\text { wall }\end{array}$ \\
\hline$k_{\mathrm{p}}^{\prime}$ & Ratio of the oxygen partition coefficients $\left(k_{\mathrm{p}}^{2} / k_{\mathrm{p}}^{1}\right)$ \\
\hline$M_{\text {MassTransfer }}$ & The mass transfer rate \\
\hline$M_{\text {Kinetics }}$ & The reaction rate \\
\hline & Storage time (days) \\
\hline & Package volume $\left(\mathrm{m}^{3}\right)$ \\
\hline
\end{tabular}

\section{INTRODUCTION}

For the purpose of package design and optimisation, it is important to consider the deteriorative reactions that take place in the food product. In many food products, these reactions are dependent on oxygen concentration, which directly affects the rate of oxidation of vitamins, lipids, pigments and proteins (Quast \& Karel, 1972).

Oxygen permeates through many package materials and its concentration inside the package changes during storage. A mathematical model to describe the concentration of dissolved oxygen is therefore important for both food and packaging producers. For the food producer, because oxygen influences product shelf-life, and for the packaging industry because the oxygen barrier of packaging materials can be optimised.

The mathematical modelling of oxygen uptake by packaged foods has been mainly applied to dried and fatty foods (Quast \& Karel, 1971, 1972; Quast et al., 1972; Ragnarsson \& Labuza, 1977). For liquid foods, several studies report the effect of oxygen on quality degradation during storage, but few of them report changes of oxygen concentration. More scarce are studies where the changes are mathematically modelled. Roig et al. (1994) studied the effects of some additives in single strength orange juice stored in Tetra Brik $\Lambda$ septic packages and dissolved oxygen concentration was measured as a function of time for several temperatures; however, no mathematical model was applied. Mack et al. (1976), Singh et al. (1976) and Hsieh and Harris (1993) studied the kinetics of oxygen uptake by liquid foods during storage considering the kinetics of ascorbic acid degradation. These studies were carried out with unpacked products. Singh (1974) developed a mathematical 
model to describe ascorbic acid and dissolved oxygen concentration changes in an infant formula packaged in glass bottles and stored at $7^{\circ} \mathrm{C}$; this model was based on Fickian diffusion of oxygen accompanied by a second-order chemical reaction in the liquid food. Sadler (1984), using a similar model, made a comprehensive study on the prediction of quality losses in a liquid food, considering various polymeric packaging materials; methods for determination of oxygen solubility in the fond and polymers, diffusion coefficients of oxygen in the food and polymers, as well as the oxygen permeation rate and the oxidation rate of the food, were also presented. Barron et al. (1993) reported a study where a finite element method was applied to the modelling of simultaneous oxygen diffusion and chemical reaction in packaged apple juice, stored at $25^{\circ} \mathrm{C}$, using a cylindrical high-density polyethylene package (top and bottom insulated). No works were found on modelling of oxygen changes in liquid products packaged in aseptic cartons.

The objectives of this study were: (1) to develop a mathematical model to describe the concentration of dissolved oxygen during storage in a packaged liquid food, considering both oxygen transfer through the package and oxygen consumption by deteriorative reactions; and (2) to assess the validity of the model for aseptically packaged orange juice stored at different temperatures. Data reported in literature were also used to further test the model.

\section{MATHEMATICAL MODELLING}

The oxygen concentration inside a packaged liquid food without headspace depends on (i) the initial concentration upon packaging; (ii) oxygen permeation through the package, including the seam; and (iii) oxygen consumption by deteriorative reactions. A mass balance leads to:

$$
V \frac{d\left(C_{\mathbf{O}_{2}}\right)}{d t}=\dot{M}_{\text {Mass Transfer }}+\dot{M}_{\text {Kinetics }}
$$

where $V$ is the package or liquid volume, $C_{\mathrm{O}_{2}}$ is the dissolved oxygen concentration in the juice at a time $t, \dot{M}_{\text {Mass Transfer }}$ is the mass transfer rate and $\dot{M}_{\text {Kinetics }}$ is the reaction rate. The mass transport of oxygen from the atmosphere into the packaged food product may be described as a three-step process (Fig. 1): in the first step the molecules of oxygen are transported from the atmosphere to and dissolved in the packaging material; in the second step the oxygen diffuses through the packaging material moving towards the food; and the last step consists on the desorption of the molecules from the package and their solubilisation in the food. The partition coefficients at the outside and inside wall of the material ( $k_{\mathrm{p}}^{1}$ and $k_{\mathrm{p}}^{2}$, respectively) may be different from the unity and depend on the system characteristics; for instance, when $k_{\mathrm{p}}^{1}$ is smaller than unity, the concentration at the package surface is smaller than the one at the contacting gas layer, as shown in the example sketched in Fig. 1.

Using the concept of resistances connected in series, an overall mass transfer coefficient $\left(K_{\text {overall }}\right)$ can be defined:

$$
\frac{1}{K_{\text {overall }}}=\frac{k_{\mathrm{p}}^{2}}{k_{\mathrm{p}}^{1}} \frac{1}{K_{\text {int }}}+\frac{1}{k_{\mathrm{p}}^{1}} \frac{d}{D}+\frac{1}{K_{\text {out }}}
$$


where $D$ is the diffusion coefficient of oxygen in the packaging material, $d$ is the thickness of the material, $K_{\text {int }}$ and $K_{\text {out }}$ are the mass transfer coefficients inside and outside the package, respectively. It is important to note that the barrier properties of the package will influence the magnitude of $D, K_{\text {int }}$ and $K_{\text {out }}$ values. When dealing with a high barrier material, the permeability properties of the package seam should be considered. The mass transfer rate through the package may then be described by:

$$
\left(\frac{d C_{\mathrm{O}_{2}}}{d t}\right)_{\text {Mass Transfer }}=K_{\mathrm{D}}\left(C_{\mathrm{O}_{2}}^{\text {out }}-k_{\mathrm{p}}^{1} C_{\mathrm{O}_{2}}\right)
$$

where:

$$
k_{\mathrm{p}}^{\prime}=\frac{k_{\mathrm{p}}^{2}}{k_{\mathrm{p}}^{1}}
$$

and

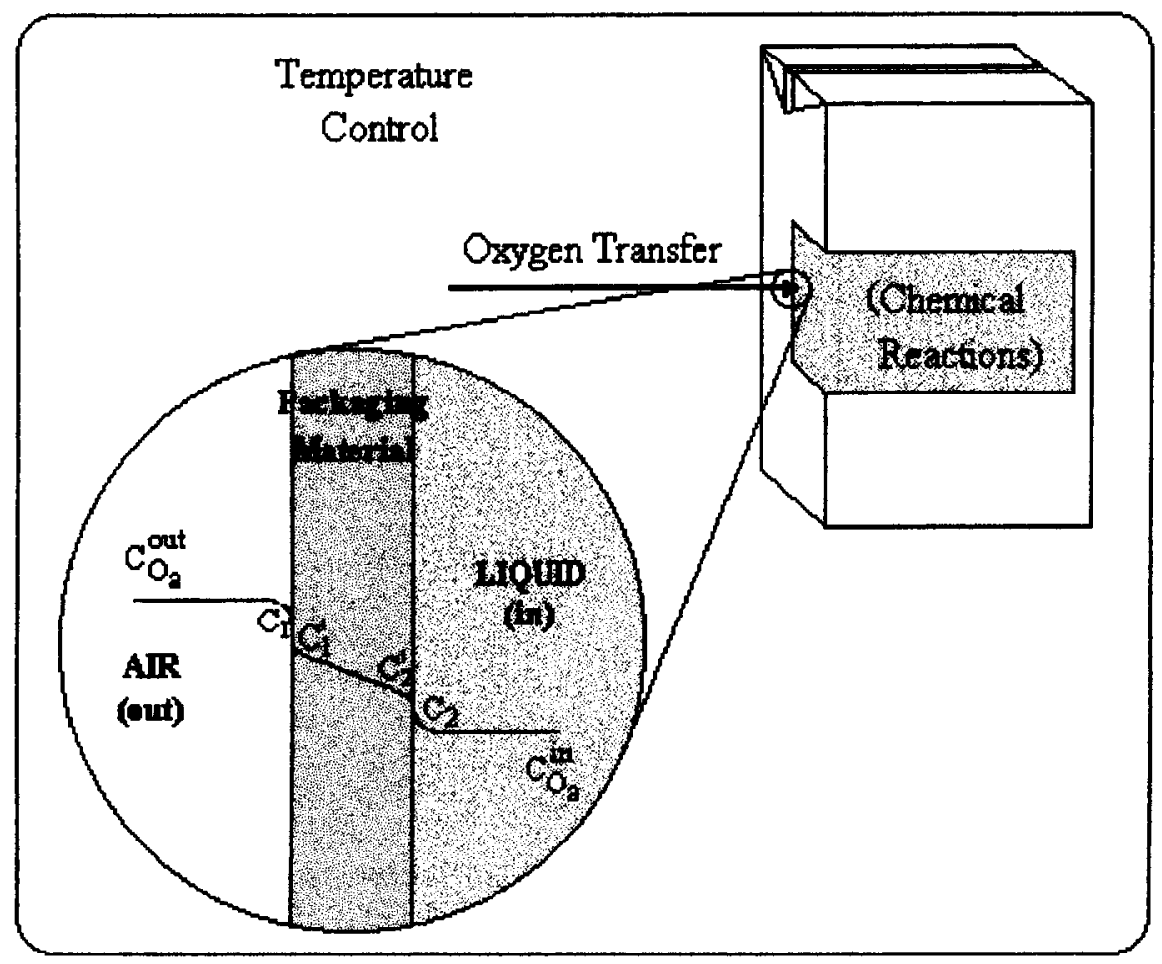

Fig. 1. Schematic representation of the mass transport of oxygen from the atmosphere into a packaged food product. 


$$
K_{\mathrm{D}}=\frac{A}{V} K_{\text {overall. }}
$$

$C_{\mathrm{O}_{2}}^{\text {out }}$ stands for oxygen concentration in the storage atmosphere, $K_{\mathrm{D}}$ is the oxygen mass transfer coefficient and $A$ is the package surface area.

For simplicity sake, the consumption of oxygen may be assumed to follow a firstorder kinetic reaction with respect to oxygen (Barron et al., 1993),

$$
\left(\frac{d C_{\mathrm{O}_{2}}}{d t}\right)_{\text {Kinetics }}=-K_{\mathrm{R}} C_{\mathrm{O}_{2}}
$$

where $K_{\mathrm{R}}$ is the reaction rate constant. Substituting eqn (3) and eqn (6) into eqn (1), rearranging and integrating the equation between time $0\left(C_{\mathrm{O}_{2}}=C_{\mathrm{O}_{2}}{ }^{\text {inital }}\right)$ and time $t$, the concentration of dissolved oxygen in the food inside the package at time $t$, $C_{\mathrm{O}_{2}}$, is given by the following equation:

$$
C_{\mathrm{O}_{2}}=C_{\mathrm{O}_{2}}^{\mathrm{eq}}+\left[C_{\mathrm{O}_{2}}^{\text {initial }}-C_{\mathrm{O}_{2}}^{\mathrm{eq}}\right] \exp [-K t]
$$

where the equilibrium concentration, $C_{\mathrm{O}_{2}}^{\mathrm{eq}}$, and the rate constant, $\mathrm{K}$, are given by:

$$
C_{\mathrm{O}_{2}}^{\mathrm{eq}}=\frac{K_{\mathrm{D}} C_{\mathrm{O}_{2}}^{\mathrm{out}}}{K_{\mathrm{R}}+k_{\mathrm{p}}^{\prime} K_{\mathrm{D}}}
$$

and

$$
K=K_{\mathrm{R}}+k_{\mathrm{p}}^{\prime} K_{\mathrm{D}}
$$

\section{MATERIALS AND METHODS}

\section{Processing and packaging}

Single Strength Valencia Orange Juice $\left(12^{\circ}\right.$ Brix $)$ was obtained from Cargill CitroAmerica, Inc. The juice was analysed for ascorbic acid, browning, ${ }^{\circ} \mathrm{Brix}$, titrable acidity and $\mathrm{pH}$ (Table 1). Browning was measured as light absorbance at $420 \mathrm{~nm}$ (Meydav et al., 1977). L-ascorbic acid was measured using an enzymatic method

TABLE 1

Characteristics of the Juice after Pasteurisation (Day 0 of Storage)

\begin{tabular}{lcccccc}
\hline Juice & $\begin{array}{c}\text { Oxygen } \\
(\text { ppm })\end{array}$ & $\begin{array}{c}\text { Ascorbic } \\
\text { acid }(\mathrm{mg} / \mathrm{l})\end{array}$ & $\begin{array}{c}\text { Browning } \\
(\text { Abs.420 nm) }\end{array}$ & ${ }^{\circ}$ Brix & $\begin{array}{c}\text { Titrable acidity } \\
\text { (g citric acid/100 g OJ) }\end{array}$ & $\mathrm{pH}$ \\
\hline A & $10.25 \pm 0.01$ & 333 & $0.149 \pm 0.008$ & $12.7 \pm 0.1$ & $2.36 \pm 0.05$ & $3.86 \pm 0.01$ \\
B & $6.47 \pm 0.02$ & 362 & $0.142 \pm 0.009$ & $12.6 \pm 0.1$ & $2.34 \pm 0.05$ & $3.85 \pm 0.01$ \\
C & $2.08 \pm 0.01$ & 396 & $0.135 \pm 0.006$ & $12.6 \pm 0.1$ & $2.35 \pm 0.05$ & $3.84 \pm 0.01$ \\
D & $1.42 \pm 0.01$ & 427 & $0.134 \pm 0.007$ & $12.6 \pm 0.1$ & $2.36 \pm 0.05$ & $3.82 \pm 0.01$ \\
E & $1.04 \pm 0.00$ & 437 & $0.132 \pm 0.004$ & $12.6 \pm 0.1$ & $2.36 \pm 0.05$ & $3.82 \pm 0.01$
\end{tabular}

$\mathrm{OJ}$, orange juice. 
(Boehringer Mannheim kit). Titrable acidity and $\mathrm{pH}$ were measured according to the AAOC methods. Two replicates were always analysed.

At Tetra Pak pilot plant (Lund, Sweden) the juice was homogenised, pasteurised at $95^{\circ} \mathrm{C}$ for $15 \mathrm{~s}$ and aseptically packaged into 11 Tetra Brik Aseptic (TBA) cartons, without headspace. The orange juice was stirred and/or deaerated prior to aseptic filling, in order to obtain batches with five different initial oxygen concentrations $(10.3,6.5,2.1,1.4$ and $1.0 \mathrm{ppm})$.

TBA cartons are made of a multilayer packaging material: low density polyethylene/paper board/aluminium foil/low density polyethylene (from the outside to the inside). The permeability of the package to air is very low due to the presence of the aluminium layer (high oxygen barrier package), with exchange of gas occurring mainly through the seam.

\section{Package permeability measurements}

The OXTRAN MH-2/20 was used to measure the oxygen transmission rate of the entire Tetra Brik Aseptic package. To test the package permeability, a Package Environmental Chamber (PEC) was used in order to obtain humidity and temperature control inside and outside the package. Nitrogen was circulated continuously through the package that was exposed to an atmosphere with $21 \%$ oxygen and $50 \%$ RH. Permeability data at $10,20,30$ and $40^{\circ} \mathrm{C}$ are reported in Table 2 .

\section{Storage experiments}

Storage experiments were conducted in temperature-controlled walk-in rooms at 4 , $8,20,30,40$ and $50^{\circ} \mathrm{C}\left( \pm 0.5^{\circ} \mathrm{C}\right)$. A total of $5 \times 120$ TBA cartons were randomly distributed into six storage rooms. Ten $(2 \times 5)$ TBA cartons were randomly collected from each storage room at different time intervals depending on temperature and analysed for dissolved oxygen concentration.

\section{Dissolved oxygen concentration measurement}

A WTW Trioxmatic EO 200 oxygen electrode in combination with a WTW OXI 200 microprocessor was used to measure the dissolved oxygen concentration in the juice.

TABLE 2

Permeability of the Package, Measured with the OXTRAN

\begin{tabular}{ccc}
\hline $\begin{array}{c}\text { Temperature } \\
\left({ }^{\circ} \mathrm{C}\right)\end{array}$ & \multicolumn{2}{c}{ Permeability } \\
\cline { 2 - 3 } & $\begin{array}{c}\text { as measured with } \text { OXTRAN } \\
\left(\mathrm{cm}^{3} /(\text { package day }) \text { at } 0.2 \text { atm, } 50 \% \text { RH }\right)\end{array}$ & $\begin{array}{c}\text { converted to } \mathrm{K}_{D} \text { values } \\
\left(\text { day }{ }^{-1}\right)\end{array}$ \\
\hline 10 & 0.009 & $4.29 \times 10^{-5}$ \\
20 & 0.014 & $6.67 \times 10^{-5}$ \\
30 & 0.023 & $1.10 \times 10^{-4}$ \\
40 & 0.038 & $1.81 \times 10^{-4}$ \\
\hline
\end{tabular}


The electrode was calibrated with an one-point calibration using water-vapour saturated air (WTW-Quick-Calibration) and equipped with a stirring device that allows a representative sample flow at the oxygen electrode. Before measurement, the packages were shaken. A small opening was made just large enough to fit the oxygen probe, which was immersed in the juice immediately after opening. The concentration of dissolved oxygen ( $\mathrm{ppm}$ ) was recorded when a steady value was displayed (approximately $60 \mathrm{~s}$ ).

\section{Data for validation of the model}

In order to further validate the mathematical model, data from Roig et al. (1994) and Barron et al. (1993) were used. Roig et al. (1994) reported a storage experiment with a similar package material, and studied the effects of some additives on dissolved oxygen content changes during storage of reconstituted single strength orange juice packed in $200 \mathrm{ml}$ Tetra Brik cartons. Barron et al. (1993) studied storage of apple juice packaged in a much more permeable packaging system (highdensity polyethylene).

\section{RESULTS AND DISCUSSION}

\section{Modelling of dissolved oxygen concentration}

The concentration of dissolved oxygen during storage changes drastically during the first days of storage and then is kept approximately constant (see Fig. 2). The changes observed during the first days of storage are caused by the rapid consumption of oxygen by oxidative reactions in the juice (Graumlich et al., 1986). After this initial period, the oxygen transported through the package and the consumption of oxygen by the oxidative reactions balance each other, keeping the level of oxygen in the product constant. This equilibrium oxygen concentration was found not to be significantly dependent on temperature and initial dissolved oxygen concentration (significance level of 95\%) in the ranges tested. Furthermore, its value was found to be significantly different from zero (significance level of $95 \%$ ), with a value of $0.110 \pm 0.008 \mathrm{ppm}$.

Changes in dissolved oxygen content in the packaged orange juice during storage were modelled for all the temperatures tested according to the model above described. The rate constant $K$ was estimated by non-linear fitting of eqn (7) to the experimental data, using the Kaleida Graph 3.0.1, 1993 Abelbeck software. This parameter showed values between 2.69 and 0.167 day $^{-1}$ (Table 3). Reaction rate constant values of the same order of magnitude were reported for oxygendependent reactions by Hsieh and Harris (1993) in water and a solution of sucrose in water, and by Mack et al. (1976) in an infant food. The estimated rate constants $(K)$ and the equilibrium concentration $\left(C_{\mathrm{O}_{2}}^{\mathrm{eq}}\right)$ values were further used to calculate the rate constant of the consumption reactions $\left(K_{\mathrm{R}}\right)$ and the mass transfer coefficient $\left(K_{\mathrm{D}}\right)$ [eqns (8) and (9)], assuming $k_{\mathrm{p}}^{\prime}$ equal to unity. The values obtained show that the mass transfer coefficient is three orders of magnitude smaller than the consumption rate constant, which is in accordance with the fast decrease in oxygen concentration and the low level of oxygen at equilibrium. It was found that the influence of $k_{\mathrm{p}}^{\prime}$ on the estimated values of $K_{\mathrm{R}}$ was very small: assuming an error of 


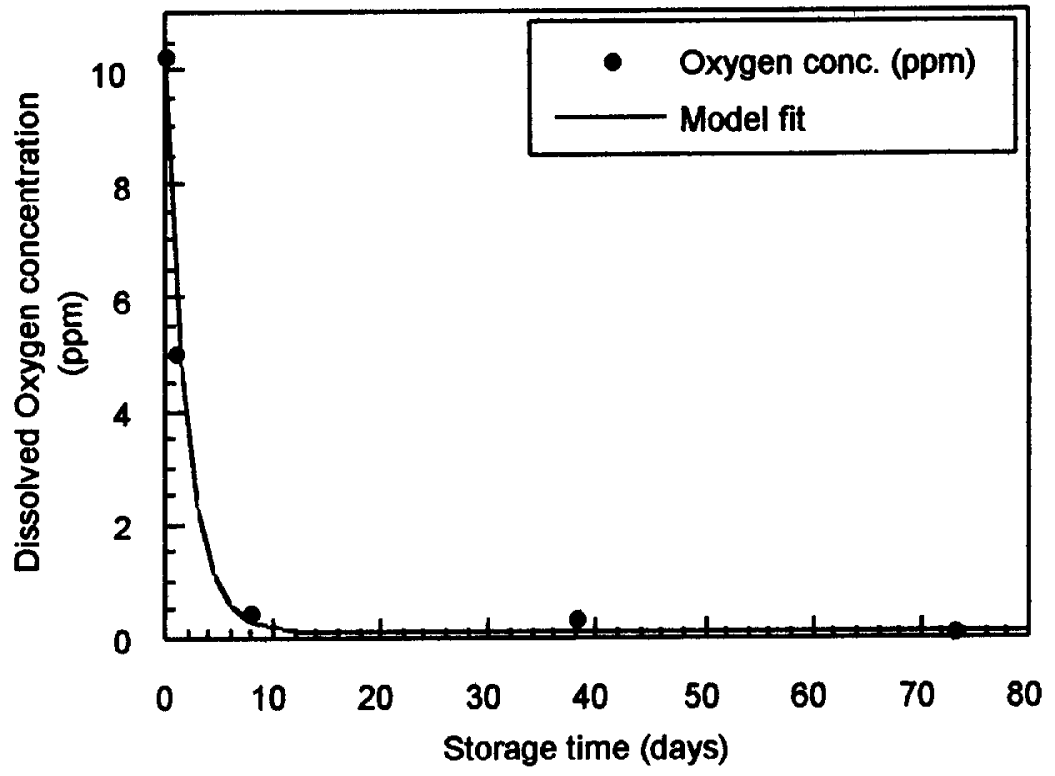

Fig. 2. Depletion of dissolved oxygen concentration during time in packaged orange juice at $20^{\circ} \mathrm{C}$, experimental data and model fit.

$\pm 10 \%$ ( $k_{\mathrm{p}}^{\prime}$ equal to 0.9 or 1.1 ), the estimated values of $K_{\mathrm{R}}$ were not statistically different from the value estimated considering $k_{\mathrm{p}}^{\prime}=1$. The dependence of the reaction rate constant $\left(K_{\mathrm{R}}\right)$ on temperature followed an Arrhenius type relationship (Fig. 3) with activation energy $\left(E_{\mathrm{a}}\right)$ of $46 \mathrm{~kJ} / \mathrm{mole}$ and pre-exponential factor $\left(K_{0}\right)$ of $82 \times 10^{6}\left(\right.$ day $\left.^{-1}\right)$.

The mass transfer coefficients are of the same order of magnitude as those mcasured with the OXTRAN, although at $40^{\circ} \mathrm{C}$ the estimated $K_{\mathrm{D}}$ value is 5-times greater than the OXTRAN value. Their dependence on temperature, for temperatures lower than $40^{\circ} \mathrm{C}$, follows an Arrhenius type equation, with an activation energy of $37.5 \mathrm{~kJ} / \mathrm{mol}$, also similar to that found for the OXTRAN values $(35.4 \mathrm{~kJ} / \mathrm{mol})$. These values reveal a sensitivity to temperature somewhat larger than the expected for diffusional processes (Garrote et al., 1988; Rodger et al., 1984) and may be due to the effect of temperature on oxygen solubility in the package and in the juice.

\section{Validation of the model}

Because of the fast decrease in oxygen concentration, our data do not allow for a very accurate assessment of the proposed mathematical model. Therefore, the adequacy of the model to predict oxygen concentration changes in stored orange juice was further checked using two additional sets of experimental data found in recent literature: from Roig et al. (1994) and Barron et al. (1993).

Data from Roig et al. (1994) are related to the dissolved oxygen content changes during storage at $4,20,37,76$ and $105^{\circ} \mathrm{C}$. The authors report a $0.2713 \mathrm{ml}$ uptake of 


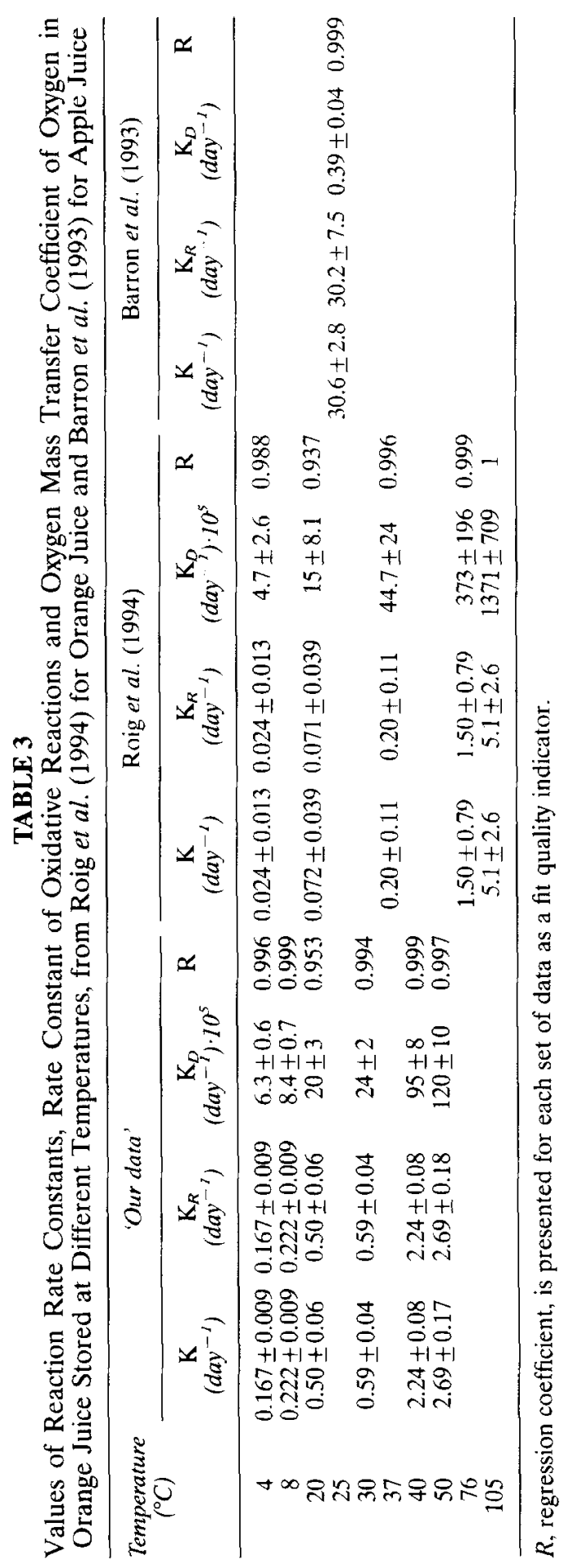




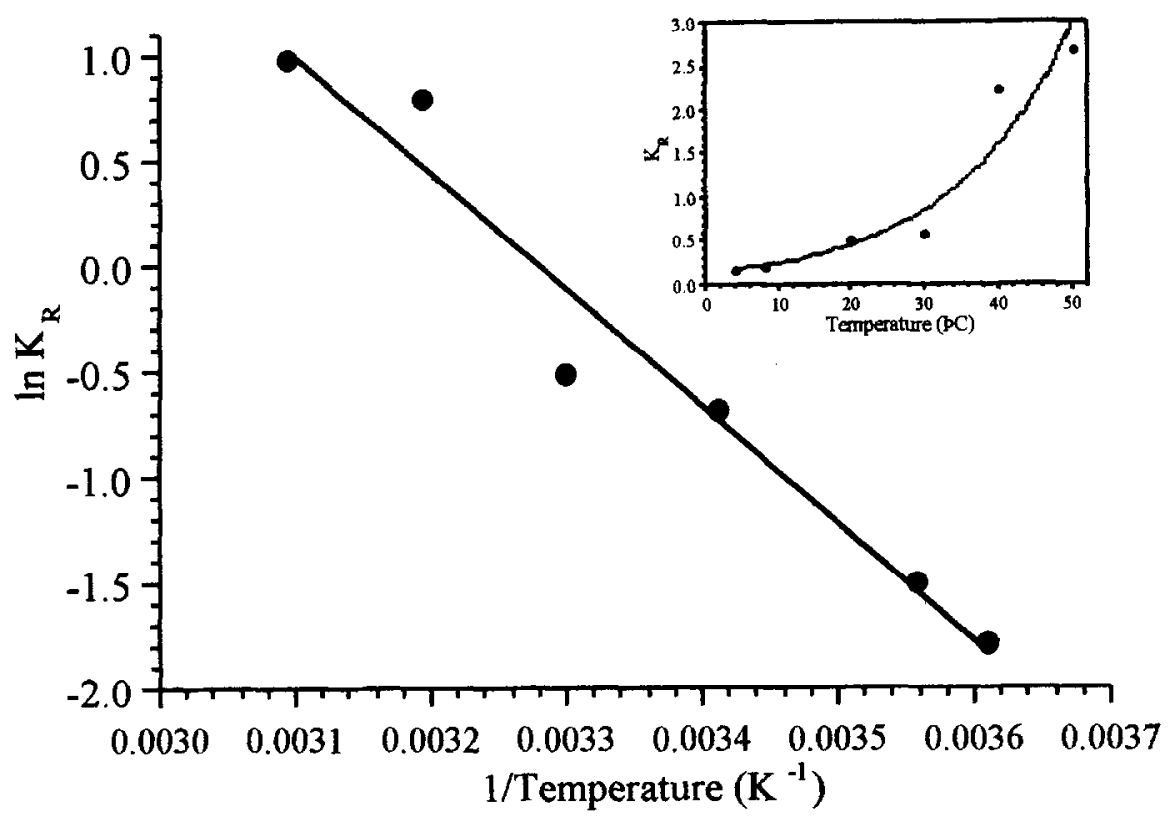

Fig. 3. Arrhenius plot for the reaction rate constant of oxygen consumption.

oxygen into a $200 \mathrm{ml}$ carton, after 1 month, when the package is stored at $18^{\circ} \mathrm{C}$ (uptake rate $\approx 0.009 \mathrm{~cm}^{3} \mathrm{O}_{2}$ /pack.day), which is similar to the results reported in the present work (Table 2). Using our model, a good correlation between experimental and predicted dimensionless oxygen concentration values was observed. Estimated values of the reaction rate constants, rate constant of oxidative reactions and oxygen mass transfer coefficients are presented in Table $3[K$ values were estimated by simultaneous optimisation of several isothermal experiments, using a Fortran program based on the Simplex method (Nelder \& Mead, 1965)]. The oxidative reaction rate constants showed an Arrhenius type dependency on temperature with an activation energy of $46 \mathrm{~kJ} / \mathrm{mol}$ (similar to that reported in the present work) and a pre-exponential factor $\left(K_{0}\right)$ of $12.5 \mathrm{E} 6\left(\right.$ day $\left.^{-1}\right)$. The estimated equilibrium oxygen concentration was $0.582 \mathrm{ppm}$. This value is higher than the one obtained in our study. This difference may be related to the importance of the seal on oxygen exchanges: the smaller the package, the greater the relative contribution of the seal to the total oxygen uptake.

Data from Barron et al. (1993) are related to changes in dissolved oxygen content of apple juice samples stored at $25.0 \pm 0.2^{\circ} \mathrm{C}$ and $45 \pm 3 \%$ of $\mathrm{RH}$ (in a controlled atmosphere chamber), in $0.771 \mathrm{HDPE}$ cylindrical packages (top and bottom insulated). Authors report an average oxygen permeability constant for HDPE of $10600 \mathrm{cc}-\mathrm{ml} / \mathrm{m}^{2}$.atm.day ( $\approx 98.2 \mathrm{ml}$ of $\mathrm{O}_{2} /$ pack.day). This material is much more permeable to $\mathrm{O}_{2}$ than those tested before, and therefore the relative importance of the oxygen transfer through the package should be higher, allowing for a better test of the model proposed in the present work. Values of the rate constant, rate constant of oxidative reactions and oxygen mass transfer rate are shown in Table 3 . 


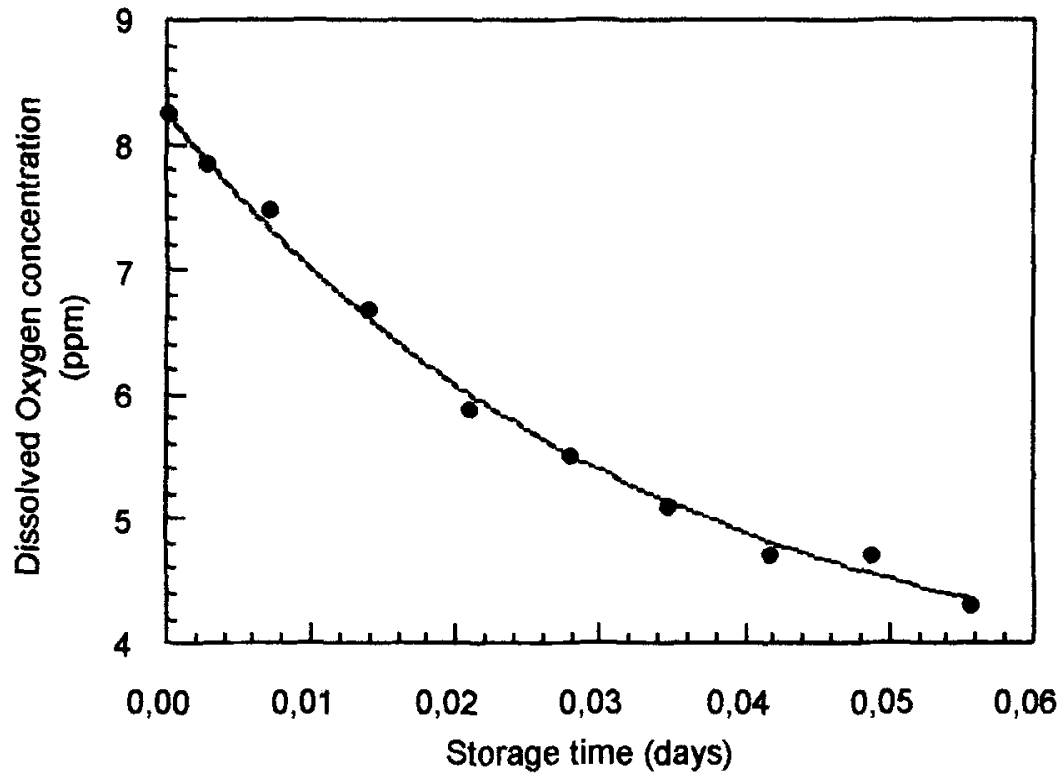

Fig. 4. Depletion of dissolved oxygen concentration during storage of apple juice at $25^{\circ} \mathrm{C}$ : experimental data from Barron et al. (1993) and model fit.

The estimated equilibrium oxygen concentration was $3.49 \pm 0.23 \mathrm{ppm}$. Figure 4 shows that the model fits the experimental data very well.

\section{CONCLUSIONS}

A model combining oxygen transfer through the package and oxygen consumption within the package, assuming no oxygen stratification in the juice, described well the oxygen changes in packaged orange juice stored at temperatures from 4 to $50^{\circ} \mathrm{C}$.

It was found that the oxidative reactions in juice packed in Tetra Pak are limited by the mass transfer through the package being high enough to maintain a residual oxygen concentration in the juice. The package permeability was much smaller than the oxidative rate constant.

The model was also applied to reported data, including packaging materials with a much lower barrier to oxygen, also with good results.

\section{REFERENCES}

Barron, F.H., Harte, B., Giancin, J. \& Hernandez, R. (1993). Modelling of oxygen diffusion through a model permeable package and simultaneous degradation of vitamin $\mathrm{C}$ in Apple juice. Packaging Technology and Science, 6, 301-309.

Garrote, R.L., Silva, E.R. \& Bertone, R.A. (1988). Effect of freezing on diffusion of ascorbic acid during water hcating of potato tissue. Joumal of Food Science, 53, 473-487. 
Graumlich, T.R., Marcy, J.E. \& Adams, J.P. (1986). Aseptically packaged orange juice and concentrate: a review of the influence of processing and packaging conditions on quality. Journal of Agriculture and Food Chemistry, 34, 402-405.

Hsieh, Y.P. \& Harris, N.D. (1993). Effect of sucrose on oxygen uptake of ascorbic acid in a closed aqueous system. Journal of Agriculture and Food Chemistry, 41, 259-262.

Mack, T.E., Heldman, D.R. \& Singh, R.P. (1976). Kinetics of oxygen uptake in liquid foods. Joumal of Food Science, 41, 309-312.

Meydav, S., Saguy, I. \& Kopelman, I.J. (1977). Browning determination in citrus products. Journal of Agriculture and Food Chemistry, 25, 602.

Nelder, J.A. \& Mead, R. (1965). A Simplex method for function minimization. The Computer Journal, 7, 308-313.

Quast, D.G. \& Karel, M. (1971). Effects of oxygen diffusion on oxidation of some dry foods. Journal of Food Technology, 6, 95-98.

Quast, D.G. \& Karel, M. (1972). Computer simulation on storage life of foods undergoing spoilage by two interacting mechanisms. Journal of Food Science, 37, 679-683.

Quast, D.G., Karel, M. \& Rand, W.M. (1972). Development of a mathematical model for oxidation of potato chips as a function of oxygen pressure, extent of oxidation and equilibrium relative humidity. Journal of Food Science, 37, 673-678.

Ragnarsson, J.O. \& Labuza, T.P. (1977). Accelerated shelf-life testing for oxidative rancidity in foods-a review. Food Chemistry, 2, 291-308.

Rodger, G., Hastings, R., Cryne, C. \& Bailey, J. (1984). Diffusion properties of salt and acid into herring and their subsequent effect on muscle tissue. Journal of Food Science, 49, 714-720.

Roig, M.G., Bello, J.F., Rivera, Z.S. \& Kennedy, J.F. (1994). Possible additives for extension of shelf life of single strength reconstituted juice aseptically packaged in laminated cartons. International Journal of Food Science and Nutrition, 45, 15-28.

Sadler, G.D. (1984). A mathematical prediction and experimental confirmation of food quality loss for products stored in oxygen permeable polymers. PhD thesis, Purdue University, USA.

Singh, R. P. (1974). Computer simulation of liquid food quality during storage. PhD Thesis, Michigan State University, U.S.A.

Singh, R.P., Heldman, D.R. \& Kirk, J.R. (1976). Kinetics of quality degradation: ascorbic acid oxidation in infant formula during storage. Journal of Food Science, 41, 304-308. 